\title{
The Problem with the Problem of Evil
}

\author{
Shane Andre \\ California State University, Long Beach, USA \\ Email: sandre20@roadrunner.com
}

How to cite this paper: Andre, S. (2021). The Problem with the Problem of Evil. Open Journal of Philosophy, 11, 336-354. https://doi.org/10.4236/ojpp.2021.112023

Received: April 19, 2021

Accepted: May 24, 2021

Published: May 27, 2021

Copyright (c) 2021 by author(s) and Scientific Research Publishing Inc. This work is licensed under the Creative Commons Attribution International License (CC BY 4.0).

http://creativecommons.org/licenses/by/4.0/

\begin{abstract}
The problem of evil has been around for centuries but as yet no consensus exists as to its significance for atheism or theism. After a brief historical review, I focus on the debate between two leading contemporary philosophers, Rowe and Plantinga, and argue that neither has succeeded in resolving the evidential version of the problem of evil. It is time to turn from the theological issue to practical issues about pointless suffering. Using a common sense approach, I argue that there are countless cases of pointless suffering and that they deserve our undivided attention.
\end{abstract}

\section{Keywords}

Friendly Atheism, Skeptical Theism, Pointless Suffering, Problem of Evil, Holocaust, Bambi Case

\section{Introduction}

The problem of evil has been around for a long time. It is usually posed in terms of extreme suffering, especially if intense and prolonged, regardless of whether it is physical pain, like a burn or crushing blow, or emotional distress, like grief or gripping fear. Hume attributed his version of the problem of evil to Epicurus, a Greek philosopher who lived about the third century BCE. While that attribution is doubtful, for his argument cannot be found in the extant works of Epicurus, few of which have survived, Hume may have made use of it for rhetorical effect. In the age of reason it could not hurt to associate your ideas with the ancients before the rise of Christianity.

There can be no doubt, however, that St. Augustine (Sparrow, 1947) in the fifth century was already aware of the problem of evil, for he developed two doctrines-the sinfulness of man and the free will defense-to deal with it. According to Augustine, God endowed man with a special gift-the gift of freedom. Unlike other animals, which were guided by instinct, man was free to obey or 
disobey God's instructions. God forbade Adam and Eve to eat of the tree of knowledge, but tempted by the serpent-a metaphor perhaps for their curiosity-they disobeyed God and as a result, they and their progeny were expelled from paradise. Augustine saw suffering as the result of sin, sin as the result of turning away from God, and God of course as all-powerful, all-knowing, and all-good. These ideas are still popular with believers today, though they may give less weight to the ideas of original sin and hell than did their famous predecessor.

Leibniz (Theodicy, 1710), the great German philosopher and polymath of the seventeenth century, who was a contemporary of Newton and vied with him over the invention of the calculus, coined the term "theodicy" from the Greek words for justice and God, "to justify the ways of God to man." He was the first to suggest the greater good defense in conjunction with the free will defense: some goods with a smidgeon of bad are better than the same goods without that smidgeon. He compared two generals with illustrious careers, one who is battle-scarred and the other who has won his battles without the scars. Leibniz thought it obvious that the battle-scarred general was more worthy. We don't have to agree with him, but Leibniz had an important insight and he took advantage of it.

Perhaps the world is better with some evil in it than it would be without any evil. It's true that a world without sentient beings like humans and other animals might be devoid of suffering, but wouldn't it be inferior to a world like our own where there are multitudes of sentient beings and, yes, some suffering but also glorious delights? That is why Leibniz maintained that this is the best of all possible worlds, not because it was free of suffering, but because it offered no more suffering than was necessary for the great good it permitted-human freedom. That is why he called this the best of all possible worlds-the kind of world you would expect God, the greatest possible being, to create.

Hume (Dialogues Concerning Natural Religion, 1779) may have been the first major philosopher in the modern period to make explicit use of the problem of evil to challenge the kind of theism Leibniz represented. Here are the premises of his argument (in my own words):

If God is omnipotent, he is able to eliminate evil;

If God is wholly good, he wants to prevent evil as far as possible;

If God is both able and willing to prevent evil, there is no evil;

But there is evil.

From these premises it follows, not that there is no God, but that God is limited either in power or in goodness. For Christians, that was tantamount to denying the existence of God, for they regarded God as unlimited in power, wisdom, and goodness. As a result, Hume is often considered to be an atheist. But, as I and others have argued, that does not mean that Hume was a positive atheist-one who believes that there is no God. While Hume was no theist in the Christian sense, perhaps it is best to characterize him as a limited theist (Andre, 
1993) or as a religious skeptic. (As scholars remind us, all of us are skeptics about the existence of some gods, like Baal and Zeus and Thor. The religious skeptic ups the ante by having doubts about the existence of any god, but he hesitates to deny their existence outright. Why give any hostages to fortune?) In an age when religious skepticism was not distinguished from atheism, Hume, concerned about his hard-earned literary reputation, left one of his greatest works, Dialogues Concerning Natural Religion, to be published only after his death. Even then, in the epilogue he saw fit to hide his religious doubts by allowing Pamphilus, the narrator of the Dialogues, to award the palm of victory to Demea, the conventional theist and least perspicuous character in the work. (Dialogues, Part XII)

Voltaire, roughly a contemporary of Hume who followed him on an ill-fated visit to England, used literature, not philosophy, to pillory Leibniz's best of all possible worlds. Though Voltaire was no friend of organized religion, he was no atheist; as he said, "If God did not exist, it would be necessary to invent him." After the Lisbon earthquake of 1755, which killed more than 50,000 people, many of them churchgoers, as it occurred on a Sunday morning, Voltaire wrote Candide to mock Leibniz's ideas. As is well-known, Candide is the story of an absurd hero who always expects the best but ends up with the opposite. In the end, it is a good thing for him to limit himself to tending his garden.

Clergyman William Paley (1802) ignored Hume's critique of the argument from design and his version of the problem of evil. Indeed, Paley supported the idea of design with a famous analogy about the complexity of a watch and that of (say) the eye, which became the locus classicus of the design argument, the one likely to appear in selected readings on religion. Support for the idea of design did not change significantly until Darwin's On the Origin of Species arrived on the scene in 1859. As is well-known, Darwin's theory of natural selection offered a science-based alternative to the theological theory of the Designer in Chief. Ironically, though Darwin had begun his career as a devotee of Paley's approach, before the century was over he set it aside in favor of a more naturalistic approach. Though the death of his favorite daughter Annie may have disposed him to question the benevolence of God, it led Darwin, not to endorse the problem of evil and outright atheism, but to agnosticism (Darwin Correspondence Project, Letter to John Fordyce, 7 May 1879).

Despite the longevity of the problem of evil, it remains contested ground today, hundreds if not thousands of years later. The battle between theists and atheists, believers and nonbelievers, rages on for readers' minds, as a glance at philosophy journals and booklists will confirm. An enquirer might well ask: What is the state of play today? Are we in the twenty-first century any nearer a consensus as to which side is gaining ground over the other, than people were in the eighteenth century? Given the volume of literature on the subject and the subtlety of many of its authors, that would be an impossible undertaking for anything short of a book. To make it possible within the compass of an article, I propose to concentrate on two leading figures in the field, William Rowe, a 
self-confessed atheist and inventor of a new brand he calls "friendly atheism", and Alvin Plantinga, who has not only single-handedly revived interest in theism but also inspired others to band together under the banner of "skeptical theism."

While I don't pretend that friendly atheism and skeptical theism are the last word on the problem of evil, I believe that Rowe and Plantinga have advanced our thinking on the subject beyond that of Hume and Leibniz, and hence warrant fresh attention. That advance may encourage some of us to think that we are drawing closer to a definitive outcome than was the case before, but I will argue for three conclusions: 1) that Rowe's famous example of the burned fawn fails to make a compelling case for pointless suffering; 2) that Plantinga's "possibilities" have no cash value and that his version of the free will defense is as controversial as other forms of libertarianism; and 3) that, despite some advance on refining the problem of evil, it is time to turn from the theological issue of pointless suffering, over which progress toward consensus seems dead-locked, to consider a more mundane but plausible alternative.

\section{Are God and Evil Incompatible?}

In the twentieth century the problem of evil developed into two versions, commonly called the logical version and the evidential version. The distinction is important, for many philosophers, believers as well as nonbelievers, are prepared to admit that the logical version of the problem of evil is now closed, whereas the evidential version is still open. This is one area where one can point to progress in dealing with the generic problem of the problem of evil.

On the face of it, there is something odd in the conjunction of God and evil. How can the supreme good in the universe co-exist with something whose non-existence would make the universe better off? Sensing the tension between the idea of God and the idea of evil, many people found it easy to conclude that God and evil are incompatible, so that the reality of one excludes the reality of the other. There are two ways of dealing with the alleged incompatibility. The first is to deny the reality of evil, as we find in Alexander Pope's poem Essay on Man:

All nature is art unknown to thee;

All chance, direction which thou canst not see;

All discard, harmony not understood;

All partial evil, universal good;

And, spite of pride, in erring reason's spite,

One truth is clear, Whatever is, is right.

In Hume's Dialogues, Demea tries the same tack, telling his companions,

The world is but a point in comparison of the universe; this life but a moment in comparison of eternity. The present evil phenomena, therefore, are rectified in other regions, and in some future period of existence. And the eyes of men, being then opened to larger views of things, see the whole 
connection of general laws, and trace, with adoration, the benevolence and rectitude of the Deity through all the mazes and intricacies of his providence.

To which Philo replies by pointing out the asymmetry between pain and pleasure. Many people would prefer the absence of five minutes of agonizing pain to an hour of undiluted pleasure. But, more to the point, the illusion of pain is not what we expect from an omnipotent and wholly good creator.

The second tack is to deny the reality of God, as J. L. Mackie (1955) famously does in his article "Evil and Omnipotence." By supplementing Hume's argument with a couple of additional premises, Mackie argues that the existence of evil is incompatible with the existence of an omnipotent, omniscient, and perfectly good being. This quick victory for atheism was shortly reversed. Theists made the logical point that, on the contrary, God and evil must be compatible, since the following set of propositions is perfectly consistent:

1) God exists.

2) Evil exists.

3) God has a morally sufficient reason for permitting evil.

Clearly, if (1) and (2) are consistent with (3), they must be consistent with each other. The defeat of the logical version of the problem of evil was an initial victory for theism and there was no need for atheists to deny it. As Rowe (1978) confessed, the logical version was a non-starter.

\section{Is Evil Evidence against God?}

But the battle wasn't over. Rowe (1979) and his allies fell back on the evidential form of the problem of evil: while the diversity and magnitude of evil in the universe is compatible with the God-hypothesis, evil by itself can still count as evidence against God and make it more reasonable to believe that there is no God than otherwise. To illustrate this strategy by an analogy, suppose all we know is that Greg has the lowest marks in his class; this fact is compatible with his passing the class, once we later learn that nobody failed the class, but by itself, without other information at our disposal, it is evidence against Greg's passing and makes it more reasonable to believe that he failed than otherwise.

Rowe took for granted that the basic form of evil is gratuitous or pointless suffering, whether it is suffering caused by natural disasters, like earthquakes and drought, or by natural accidents, like birth defects and mental illness; or suffering caused by moral evils, like slavery and genocide, or personal vices, like selfishness and culpable ignorance. In the eighteenth century the famous example of natural evil was the Lisbon earthquake, but in the twentieth century it became the Holocaust, when the Nazi regime carried out the mass genocide of millions of men, women, and children on the basis of a trumped up ethnic mythology. (Anne Frank and her mother were included in that mass killing).

Rather than turn to general examples of natural and moral evil, however, Rowe chose to focus on a particular case of what is, or appears to be, pointless 
suffering. Widely discussed in the literature, this came to be known as the Bambi case, in reference to the children's bedtime story, but with a very different ending. In Rowe's version, a fawn is trapped by a distant forest fire. Presumably, the fire was started by lightning, not arson or human negligence, so it is a clear example of a natural evil, and it causes the fawn to be horribly burned. Days later, after lingering in terrible pain, the fawn dies. Since, as far as we know, God could have prevented such suffering without losing a greater good or permitting an evil equally bad or worse, Rowe concludes that the fawn's suffering appears to be pointless. Even if it could be justified by some greater good, like improved forest management practices, it is only one of countless cases of such suffering, large and small, and it is unlikely that all of them could be justified by God-justifying reasons: i.e., some of them are really pointless.

That is the first step in Rowe's argument. It is of course a piece of inductive reasoning, and Rowe uses it to mount a full-scale deductive "argument for atheism based on evil." His argument can be simplified by using "God" in place of the more cumbersome expression "an omnipotent, omniscient, wholly good being," as follows:

1) There exist instances of intense suffering which God could have prevented without thereby losing some greater good or permitting some evil equally bad or worse.

2) God would prevent the occurrence of any intense suffering he could, unless he could not do so without thereby losing some greater good or permitting some evil equally bad or worse.

3) Therefore, God does not exist.

The argument is valid, so the question whether it is sound depends on whether its premises are true. Rowe points out that, since the second premise is a necessary truth, expressing part of the meaning of "God", the crux of the argument is premise one, supported by the Bambi case. While he admits that the latter doesn't prove that premise one is true, he contends that it makes it reasonable to believe that it is true. Rowe might have added that probabilistic arguments are accepted every day in science and in practical life. After all, we can't prove that all humans are mortal, but on the basis of what we know about the past and human biology, it is exceedingly probable.

Rowe is aware that the theist can reject the first premise and thereby the conclusion. In fact, he later suggests that this move is the theist's best response. Using one or more of the traditional theistic arguments, or the appeal to religious experience, or the best explanatory hypothesis of phenomena, the theist can turn the argument upside down by arguing that, since God exists (the negation of the original conclusion), its first premise must be false (the negation of the original first premise). The question then becomes: which is more likely, on the basis of our total evidence, the existence of pointless suffering or the existence of God. On this point the theist and his opponent must agree to differ.

While Rowe's double-barreled argument implies that the theist is mistaken, he grants that theism is not necessarily irrational. The distinction between the truth 
and rationality of a belief is surely correct. Suppose you and I have different beliefs about the time because we don't have access to the same evidence. Knowing that the power has been off for an hour, I know that the clock on the wall is wrong, but, if you don't know about the power outage, you may be perfectly justified in believing that the time on the clock is correct, as it has always been reliable in the past (my example). In this case, my belief can be both true and rational, whereas your belief is false but nevertheless rational. I would have the same belief as you but for having access to additional evidence. Rowe uses this kind of distinction to explain what he means by "friendly atheism." The friendly atheist is one who believes that theism is false but not necessarily irrational. He may be compared to the unfriendly atheist, who believes that theism is both false and irrational, and the indifferent atheist, who believes that theism is false but has no opinion on its rationality, perhaps because he has never considered it as a separate question.

I believe that the concept of friendly atheism is interesting and useful, as it grants the theist something-his position is not necessarily irrational-and it is designed to allow the atheist to maintain the superiority of his position in point of truth. Nevertheless, it does raise a problem. What does the atheist know about suffering that the theist does not? It can't be the existence of pointless suffering, for as we will see, the theist has his own reasons for doubting the existence of such suffering. No doubt many cases of suffering appear to be pointless, but as many theists have pointed out, given human fallibility and the limits of human knowledge, there is a gap between appearance and reality, and atheists like Rowe have not closed that gap. As Stephen Wykstra (1996: p. 126) says, "Looking around my garage and seeing no dog entitles me to conclude that none is present, but seeing no flea does not; and this is because fleas, unlike dogs, have low seeability; even if they are present, we cannot reasonably expect to see them in this way." In some cases the absence of evidence for something is evidence that something is absent, as in the case of a bomb threat that on investigation turns out to be a hoax, but in other cases the absence of evidence is another story. Until the microscope was invented, there was no direct evidence of forms of life too small to be seen with the naked eye, but it would have been rash to conclude that no such forms of life were possible. Similarly, we have no direct evidence of the existence of extra-terrestrial intelligent life, but would that be enough to justify us in believing that "we are alone in the universe"?

If the atheist cannot make good on his claim to know something about suffering that the theist does not, then it is hard to see how his position relative to the theist is like that between me and you in the clock situation. There it makes sense to say that, though both of us are rational, only one of us has a true belief, but it is paradoxical to contend that the theist and atheist are privy to the same information but only one of them has a true belief based on that information. For that to be possible, at least one of the parties must have misunderstood the original information or violated the equal information hypothesis by assuming that one of them has access to privileged information (Andre, 1985: p. 215). 
The Bambi case for natural evil has been supplemented in two ways. First, the argument for pointless suffering can be extended to moral evil, as Bruce Russell (1996) does. He cites a tragic case of actual evil in which a five-year-old girl was brutally beaten, raped, and strangled by one of the three men in her mother's household. We human beings can see no morally justifying reason for such a heinous act, but obviously it doesn't follow, from that fact, that there is no such reason. Perhaps God has a reason that is beyond our ken. To explore this possibility, Russell explores three "Noseeum" principles, rejects the first two and accepts the third: S's failure to see $\mathrm{X}$ is a reason to believe that $\mathrm{X}$ isn't there if and only if X's not being there is part of the best explanation of S's failure to see $X$ (or is deducible from statements which are). In Russell's view, the non-existence of God is part of such an explanation-though he doesn't put it that simply-so if there is no God, it follows that there is no God-justifying reason for the little girl's suffering. Surely, he is right if there is no God, but the theist may accuse the atheist of begging the question by assuming that in fact there is no God. Russell is also right in suggesting that, if some person was present who could intervene to prevent the crime against the child, that person would be morally obligated to do so, but again the theist will insist that God may have grand purposes that go beyond immediate intervention. It is not clear, therefore, that the Sue case, as it has come to be called, adds much weight to the Bambi case.

The second supplement to the Bambi case was provided, ironically, by a well-known theist, Peter van Inwagen (2006). He devotes a chapter of The Problem of Evil to "The Suffering of Beasts." Beasts, of course, are nonhuman animals, and van Inwagen takes for granted that animal suffering has gone on for millions of years-suffering caused by predation and extinction events, whose scale dwarfs that of Bambi. Lacking free will of the human sort, this suffering cannot be justified by the popular free will defense, as can human suffering, so some theists have contended that animal suffering was due to the corruption of nature; as Plantinga (1974: p. 58) says, "Something similar holds here; possibly natural evil is due to the free activity of nonhuman persons [e.g., Satan and his minions]" whose rebellion against God preceded that of man. Rather than accept this traditional view, van Inwagen proposes a different explanation. For him, God had a choice between creating a world like our own, with sentient animals capable of feeling pleasure and pain, and creating a massively irregular world, vastly different from our own. Since the latter world would have frustrated the divine purpose, God chose to create our kind of world. I mention this alternative not to support or attack it, but only to make the point that the problem of animal suffering, which goes deep into the prehuman past, is a headache for theists, quite apart from Rowe's fawn.

\section{Plantinga and the Case for Theism}

Despite the popularity of the Bambi case, many theists have challenged it and obliged Rowe to reframe his position in later articles, not as well known, but in 
the opinion of his critics, subject to the same difficulties and perhaps others. Rather than review that literature, I propose to look at an article by Plantinga (1996). While he has other works on the subject, in this one he targets Rowe's Bambi case, skewering it in a way that has encouraged other theists to pursue it avidly under the banner of skeptical theism. The general theme of skeptical theism is that human knowledge is very limited, especially of God and his purposes and doings. We may think we know that the universe originated in the big bang almost fourteen billion years ago, but we have no idea why or how the big bang began, if indeed it had a beginning. How come the entropy of the universe was so low at that point but has only increased since then and will eventually lead to the end of the physical universe as we know it today? We know that our bodies perish after death, but, as far as we know, isn't it possible that our spirit or soul will live on until the day of final judgment? Skeptical theists don't maintain that these things are so, only that they are possible. No one has proved that they are impossible. Nothing we know rules them out.

Plantinga invites us to consider the case of a child who dies a lingering and painful death from leukemia. Why couldn't God-an omnipotent, omniscient, wholly good person (Plantinga, 1983) - prevent that suffering for the child and her family, who may be good Christians? While he admits that his answer would not be suitable for pastoral care, Plantinga (p. 73) has no hesitation about the correct answer:

True enough: we can't see what reason God, if there is such a person, has for permitting this child to suffer in that way. But (granted that it is indeed possible that he have a reason) can we just see that he doesn't have a reason? Perhaps his reason lies in some transaction involving free creatures of sorts we have little conception of. Perhaps God's reason involves a good for other creatures, a good for some other creature such that God can't achieve that good without permitting the evil in question. Or perhaps his reason involves a good for the sufferer, a good that lies in a future life.

For the atheologian-his new word for atheist-to justify the conclusion that: 1) there is no outweighing good for that child, he would have to justify a flock of other propositions: 2) there is no outweighing good for the child in an afterlife; 3) there is no afterlife, or 4) even if the child has an afterlife, it will contain no good that outweighs this evil and is such that God could not achieve it without permitting this evil. Needless to say, nobody has shown that (2) (3) or (4) is false, so nobody is in a position to insist that (1) is true. As Plantinga (p. 74) adds: "Our cognitive powers are at best modest; we do fairly well with respect to medium-size dry goods, as Austin remarks, but of course there may be much that God takes into account that is entirely beyond our ken."

Plantinga (pp. 75-76) defines an evil as inscrutable if it is such that humans can't think of any reason why God would permit it to exist. But this means that practically nothing follows from the fact, if it is a fact, that some evil is inscrutable. As Plantinga observes, 
Clearly, the crucial problem for this probabilistic argument from evil is just that nothing much follows from the fact that some evils are inscrutable; if theism is true, we would expect that there would be inscrutable evil. Indeed, a little reflection shows there is no reason to think we could so much as grasp God's plans here, even if he proposed to divulge them to us. But then the fact that there is inscrutable evil does not make it improbable that God exists. (My italics)

On examining, and finding fault with, three current conceptions of probability, Plantinga (p. 79) concludes that the atheologian is doomed to disappointment: none of them supports his claim that the existence of God is improbable or unlikely with respect to the existence of " $10^{13}$ turps of evil (where the turp is the basic unit of evil)." As Plantinga (pp. 86-87) rightly observes, people have very different reactions to encountering cases of appalling evil: it may strengthen their faith in God, weaken their faith, leave their faith unchanged but perplexed, or leave the faithless with the conviction that they are right.

Plantinga (pp. 87-88) also rightly notes that a proposition which is improbable relative to one piece of evidence may be probable relative to another. Knowing only that my new neighbor has a dog, I may infer that I will hear a lot more barking nearby, but on learning later that his dog belongs to a rare breed of dogs that don't bark, I will retract my previous induction (my example). That is the beauty of induction: it can lead to error but it can also be self-correcting. Plantinga grants that even if theism were inconsistent with evil, when it comes to the total evidence, not just the evidence of evil, the theist may have non-propositional evidence in the form of personal religious experience that renders belief in God probable, if not certain, for him on the basis of that experience. It may not do so for those who have never had such an experience, but that does not belie the evidence of his own experience. We should not make the mistake of thinking that $x$ is evidence for $h$ only if everybody, or nearly everybody, is familiar with $x$, like sense-experience.

Part of his argument is plausible. Since perfect pitch in music is an innate ability that a few people possess, but most do not, we cannot rule out the possibility that something like it may be found in the innate ability to receive religious visions or communications. Though I have no such ability, that gives me no reason to deny that Plantinga and others may have that ability. Though atheists commonly think of such persons as being deluded, Plantinga (p. 91) says the shoe may be on the other foot. The theist may be inclined to think of the atheist as an unfortunate individual who suffers in his own way from a major spiritual defect, who cannot see what is open for more fortunate others to see. However, Plantinga does not address the well-known difference between the two cases. Perfect pitch can be tested by natural means, but special religious sensitivity seems to depend on self-reporting.

Plantinga is surely right to call attention to the limitations of atheism, but it is worth asking the comparative question "How do the limitations of atheism and 
theism compare?" The atheist cannot prove that there is no person like God, no afterlife, no final judgment, and so on, for all these things are possible, but what kind of possibility is this? Plantinga and others who follow him like to speak of "epistemic possibility" - for all we know about the world, certain unworldly states of affairs are not ruled out. For example, there is no contradiction in supposing that the body perishes at death but that the spirit or soul of the deceased continues to live on in some supernatural state. For that matter, it is not clear how a natural state and a supernatural state can interact, let alone be self-contradictory.

The atheist need not be shaken by the epistemic possibility of life after death. Calling upon him to rule it out is asking him to do something impossible-namely, showing that the idea of surviving death is contradictory, like the idea of a square circle. It is like asking someone to prove a negative universal statement, like "There are no unicorns in the universe," instead of a restricted one, like "There are no unicorns on earth today" (meaning of course the live animal). So the inability to prove it shows nothing. We must be cautious about claims as to what is possible. It is epistemically possible that Sue is now enjoying life in heaven-nothing we know about the physical world rules it out-but atheists attach little weight to such possibilities. After all, they are epistemic possibilities, not probabilities. Nothing we know about the world and persons rules out the possibility of Sue's heavenly state, but it would be silly to treat that possibility as if it were a live possibility, like the possibility that you will spill your drink if you are careless or not be fit to drive if you drink too much. Asking the atheist to rule out remote possibilities isn't possible. And theists know it. That's why they ask the atheist to do it, counting on his failure to do it to support their position. Admittedly, the atheist can't prove that Sue's suffering is pointless, but the theist can't prove that it isn't either. It's a draw. Best to move on.

Since the free will defense is essential to the theist's position, Plantinga has no choice but to take it on. This is unfortunate, for neither philosophers nor scientists have been able to reach a consensus as to which of the two positions on free will-compatibilism or incompatibilism-is correct. As Samuel Johnson said of free will, "All experience is for it, all reason against it." According to compatibilists-sometimes called soft determinists because they believe that the feeling of freedom is compatible with determinism-you are free if you choose to do $\mathrm{X}$ and nothing prevents you from doing $\mathrm{X}$, regardless of whether your choice was causally determined and could have been predicted by an omniscient being beforehand. You certainly aren't responsible for the genes you inherit at conception, so it's possible that you aren't responsible for anything that follows. As Schopenhauer said, "You are free to do what you will, but not free to determine what you will."

Incompatibilists, on the contrary, reject the idea that free will and determinism are compatible. That leaves open two possibilities: you can plump for determinism and the absence of real freedom-the position of hard determinism-or for real freedom and the falsity of determinism - the position of liberta- 
rianism. As I understand Plantinga and other theists who endorse the free will defense, they are libertarians. They reject determinism, at least as an explanation of human action, and also the concession that soft determinists are prepared to make for the sake of peace with determinism. (Modern physics, in any case, gives little support to universal determinism).

To illustrate the libertarian position in a concrete way, as Plantinga does in his story of Curly, the mayor of Boston, suppose Curly is offered a bribe and has the opportunity to accept or reject it. We can represent his position in the form of two worlds, A and B, which are identical in all respects at time $t$ when the bribe is offered (Hammond, 1956). At a later time $t 1$, Curley accepts the bribe in world A, but what will his counterpart do in world B at that time? Will he accept or reject the bribe? If you are a determinist, there is no question but that he will accept the bribe in world B as well, for if two worlds are identical at one stage they will be identical at a later stage. But for a libertarian the outcome could be different. Yes, Curley could accept the bribe, but since he is free in the libertarian sense, he doesn't have to do so. He could reject the bribe-not necessarily for altruistic motives, but for self-concerned ones: he judges that accepting the bribe under present conditions is too risky. How can two persons identical in every respect come to make such divergent decisions at a later time? Many people find the libertarian conception of free action unintelligible, since it seems to make free action comparable to tossing a coin.

Libertarianism seems to presuppose "the principle of alternate possibilities" (PAP): You aren't free in doing X unless you could have acted otherwise-i.e., done something else. While PAP has some intuitive appeal, Harry Frankfurt (1969) and others have shown that it is falsified by possible counterexamples. Suppose that Mary Reilly is a super scientist: she can anticipate how you plan to vote and even intervene if you don't plan to vote her way. Now you are about to vote on an important matter, but she is willing to leave the matter up to you, provided you vote as she prefers. If you do not, she is prepared to intervene and modify your vote so it accords with her wishes. In the end you decide to vote her way, so there is no need for her to intervene. In this scenario, you have acted freely, though in the nature of the case you could not have acted otherwise. (My example)

This of course is a science fiction case, but this kind of objection to PAP doesn't have to depend on science fiction. In the seventeenth century John Locke (1689) came up with a possible situation which will do as well. Suppose a guest at a drinking party drinks too much and passes out. For his guest's safety the host arranges for him to be taken to a bedroom and locked inside. During the night the guest awakens and is surprised to find himself in a strange room. $\mathrm{He}$ wonders whether to get up and leave the room, but, being comfortable, he decides to stay where he is. In doing so, he acts freely, but of course he couldn't have acted otherwise, for the exit is blocked. This example not only calls PAP into question, but conforms nicely to the compatibilist account of freedom. The sleeper is free, not because he could have acted otherwise, but because he did 
what he wanted to and nothing prevented him from doing so. Compatibilism, of course, is not the last word on the subject. But that is my point: the concept of free will has proved too contestable to bear the weight put on it by Plantinga and other theists.

\section{Common Sense and Pointless Suffering}

As far as I can see, the theological case for or against pointless suffering remains open. While Rowe has been unable to close the gap between the appearance and reality of pointless suffering, Plantinga has been unable to show that epistemic possibilities are live possibilities and, without making use of a controversial theory of free will, that there are God-justifying reasons for what appear to be cases of pointless suffering. Both philosophers proceed on the basis of understanding pointless suffering in grand metaphysical terms: it is suffering which God could not prevent without losing a greater good or preventing an evil equally bad or worse. But why must we proceed to tackle that problem in those terms? If your object is not to rule the possibility of God in or out, the question whether there is pointless suffering has a straightforward answer. Pointless suffering is suffering which is either: 1) not deserved by the sufferer, because he or she has done nothing morally wrong, or 2) not necessary for the sufferer to gain some greater good not otherwise obtainable, because the greater goods in question are no more than "possible." Since there are many instances of suffering which are neither deserved nor necessary for some greater good, it is clear that there are many instances of pointless suffering.

But we need to be cautious. How can we tell whether someone does or does not deserve to suffer, or whether their suffering is of no future benefit to them or to others? There is more than one way of doing something morally wrong. We naturally think of wrong actions like lying or cheating or driving under the influence, or worse. But there are other ways of acting wrongly, like being negligent or careless or omitting to do something that is morally required. Perhaps you refused to help a needy person when you could easily have done so, or benefitted from being a member of a group that owes its privileged economic position to the oppression of minorities in past generations. It would be difficult to establish for any adult that they have never, on any occasion, done anything wrong in that expanded sense. Maybe that's why only young children are regarded as moral "innocents." Adults have lived longer and been more exposed to frustration and temptation, so it is unlikely that any of them has escaped the brush with some form of wrong-doing.

Even so, there are differences of proportion. Even if nobody is free of minor offenses, some people are struck by extraordinary disasters they have done nothing to deserve: the young woman raped by her teacher, the mother whose child is kidnapped and murdered when she can't pay the ransom, the elderly man robbed of his life savings at gunpoint, the window strangled in a home invasion, and so on. There are also cases where ordinary people find themselves in 
extraordinary situations, like war or revolution, where they may suffer injury and death for no other reason than being on the wrong side. None of these people may be moral innocents, but given the disproportionate level of suffering they undergo, they seem to be victims of pointless suffering.

No doubt people can benefit from their own suffering or the suffering of others. When someone's project went awry, my grandmother used to say "Experience is the best teacher"-meaning, I suppose, that you learn more from your own mistakes than from observing the mistakes of others. It is one thing to be told that eating too much can lead to getting sick, and another thing to discover that fact for yourself. No wonder we have the popular saying "Experience is the name we give to our mistakes." Parents who love their children may nevertheless allow them to make minor mistakes to learn for themselves that some behavior is not worth repeating. But there is a limit to that permissiveness.

No caring parent would allow their child to eat a poisonous mushroom or be bitten by a rattlesnake or rush into a busy street without first looking, in order to find out for themselves how undesirable such behavior would be. Better to substitute a spanking or time-out for such dangerous behavior.

In other cases people may engage in risky behavior for the fun of it, to exhibit their courage or manhood, or to outface a rival. When successful, they are thrilled, and anticipation of such a thrill is probably what entices them to participate in the behavior in question. When not successful, they may of course regret the consequences of their behavior, as it can be a source of great suffering for themselves and loved ones. But it would be a stretch to call it pointless suffering, for their aim was to achieve a prized end which involved the risk, not the certainty, of suffering.

Speaking on behalf of the Irenaean theodicy, named after St. Irenaeus in the second century, John Hick (1994) proposes to regard suffering, not as punishment for sin, but as an opportunity for "soul-making." In creating man, God fashioned the body but not the soul of his creature. For that, something more was necessary: man had to engage with the problems of earthly existence and lift himself up by his own efforts. The earth was, in John Keats' words, "a vale of soul-making", in which struggle and suffering enable man to rise above the level of animals. As Hick (p. 179) says,

Men are not to be thought of on the analogy of animal pets, whose life is to be made as agreeable as possible, but rather on the analogy of human children, who are to grow to adulthood in an environment whose primary and overriding purpose is not immediate pleasure but the realizing of the most valuable potentialities of human personality.

This is a noble vision, giving suffering a positive role to play in human life but, as Hick admits, it accounts for a limited number of cases of suffering. And surely it is true that, just as suffering can lift up the human spirit, it can also crush it and leave nothing but devastation in its wake. In the school of hard knocks, perhaps only the fortunate few can pass the course of prescribed studies. 


\section{The Reality of Pointless Suffering}

Richard Swinburne (2004) proposes an epistemic principle he calls the "principle of credulity." The name is not flattering, for we commonly think of a credulous person as one who is easily taken in. Aside from the name, the principle is plausible. What it says in effect is that, if something appears to be the case, you are entitled to believe it, unless you have reason to suspect that it cannot be trusted. Though Swinburne uses it to support religious experience, it is less contentious to restrict it to more ordinary situations. For example, if you see drops of water on your window and wet patches on the ground, you are entitled to believe that it is raining, unless there is reason to think that your vision is defective or that the "rain" is produced by a sprinkler or broken water main. If someone tells you that she has a headache, you should believe her unless you have reason to think that she may be lying. By the same token, if you stub your toe and feel a jolt of awful pain, you should believe that you are in pain, and it is hard to see how you could be mistaken. But should you believe that the pain is "pointless"? Well, presumably it was an accident, so in a sense it was pointless. But in another sense you could say that it is nature's way of telling you that something bad has happened to your foot and that you may need to treat it with special care. There is pain all right, but it isn't a clear example of pointless pain.

Take another case. Your friend by all accounts is a good woman. She has a loving family, many long-time friends, and is generous to all and sundry, but on a life-saving mission-to donate blood to save the lives of others--she is hit and severely injured by a hit and run driver. She ends up in severe pain in a hospital bed and, despite valiant efforts to save her, expires in terrible pain within a few days. You have no doubt that she suffered greatly, but was her suffering "pointless"? Well, you have no reason to regard it as deserved, as it might be if your friend had made a handsome living as a secret drug dealer, responsible for ruining the lives of many young people. Nor do you have any reason to believe that she is now better off, being in heaven and enjoying the reward of eternal bliss, for you have no reason to believe that hypothesis. Nor do you believe that other people are better off for her suffering.

No doubt some good might follow it. Perhaps she left a large sum on money in her will for a local orphanage, and they received those funds to do their good work. But you have no reason to believe that her suffering was necessary for that outcome. Had she died of natural causes a year later, the inheritance would have gone to the orphanage anyway. In short, you have every reason to believe that your friend's suffering was pointless.

The same thing of course goes for the stock examples of pointless suffering in the literature: the Lisbon earthquake, the Holocaust, and the Bambi and Sue cases. They are all striking examples of pointless suffering by any ordinary standard. We should not allow that fact to be obscured by the question whether God could have prevented them without losing a greater good or preventing an evil as bad or worse. It may be interesting for theologians to consider the implications of 
our ordinary beliefs about pointless suffering for the God hypothesis, but the outcome of their reflections should not lead us to think that the existence of pointless suffering is somehow controversial, when it is not. What is controversial, as Rowe and other atheists have argued, is whether the God hypothesis is true or at least reasonable to believe. Perhaps they have not succeeded in discounting that hypothesis, but whether they have or not, that is a separate question. It need not shake our ordinary convictions about pointless suffering. It is true that appearances can be deceiving, but we can't ignore the fact that if a pot on the stove is smoking, there is probably something in it that is burning. As Groucho Marx said, "If something is absurd, don't be deceived, it probably is."

The question whether our ordinary beliefs about suffering are true or false is not unlike our ordinary beliefs about solid matter. Ordinarily we think of rocks and bricks as solid, whereas sponges and fishing nets are not. But according to physics, rocks and bricks are more like sponges than we naively think, for they are made up of large numbers of tiny atoms and are mostly empty space. Does that mean we should abandon the ordinary distinction between solid and porous matter? No, for there is a difference of scale. On the macroscopic scale of everyday life, where things can be seen as wholes, a rock is solid whereas a sponge is not. On a different scale, the microscopic scale of physics, where only a part of a whole can be seen, that part is not solid but porous and mostly empty space. Because of these differences in scale, a rock can be rightly viewed as both solid as a whole and as being made up of miniscule parts that are not solid. The two views are no more incompatible than the view that a distinguished orchestra can be made up of fine but not distinguished musicians or the view that a massive rain forest can be made up of individual trees that are small by comparison.

Similarly, suffering can be pointless for the sufferer and yet have a point for another party. Consider the myth of Sisyphus. The gods punish Sisyphus for tattling on them by sentencing him to a cruel fate: he must roll a heavy stone uphill only to have it come crashing down once it reaches the top, only to renew his labor with the same result, on and on, without end. We can presume that Sisyphus suffers from the prospect of his futile, endless labor, but we can also picture the gods gloating over their fiendish punishment. For them it has a point but it is still pointless for Sisyphus. Even if he deserves some punishment, does he deserve it for eternity? We need not suppose, then, that because suffering is pointless for the sufferer that it must be pointless, period. God may have a point in sending sinners to hell for eternity, but that doesn't mean that it has a point for them. On the contrary, their point in life may have been to avoid the prospect of hell.

It is true, of course, that suffering can have a point for someone, though they don't know it at the time. For example, a child may see no value in a painful injection, only to discover later in life that it spared her from a crippling disease. In short, we may have to wait to discover whether the suffering imposed is truly pointless. Theists often propose that we must wait until after death to discover 
the purpose of suffering, but, as atheists point out, such a claim takes for granted that such suffering has a purpose, and so it is question-begging. Pointless suffering remains a problem for the theist, and it can hardly be addressed by a story like the trials of Job. Job endures terrible tribulations but in the end he is said to be rewarded by gifts twice as good as anything he lost. True, the story shows no evidence of that expectation on his part, but if it ended with nothing but the suffering and natural death of Job, it would leave believers in doubt and dismay. Some readers are shocked when Robert Frost (1949: p. 600) imagines God to confess, "I was only showing off to the Devil, Job, As is set forth in chapters One and Two." Viewed in this light, Job's trials could be seen as another case of pointless suffering - pointless in the everyday meaning of the term.

I have no wish to deny that there are also cases where somebody considers their suffering, however agonizing and however undeserved or unnecessary, to have a point. This is possible because they believe, perhaps mistakenly, that their suffering contributes to the greater good, will be rewarded by heavenly bliss, or will allow them to rejoin loved ones in the afterlife. This is one of the ways in which human suffering differs from that of animals, for animals presumably have no such abstract beliefs. But if the greater good can be achieved without human affliction, if heaven is an illusion, or if there is no happy reunion after death, we have no option to regard such suffering as other than pointless. To claim that it might have a point for God strikes me as irrelevant.

Suffering, of course, is not the same as evil, for suffering in some cases can be justified. Bambi's suffering from her burns could be justified if it allowed her to recover and go on living a life suitable for her kind, and perhaps even Sue's beating and rape could be justified if it did not end in her death but allowed her to grow up and obtain some solace in later life for the experience, and use it to help young girls and women to avoid a similar plight. But as we know none of these better outcomes occurred. It is hard to see how such suffering is other than pointless, for it was neither deserved nor necessary for something of greater value that could not otherwise be obtained. In short, the world would be better off without such suffering. It is no accident that cases of pointless suffering, real or imagined, give rise to the problem of evil.

\section{Conclusion}

Despite the efforts of theists like Leibniz and Plantinga, it is not only doubtful whether they can dispose of the problem, but whether it is even necessary to tackle the problem in their terms, as Hume and Rowe undertake to do. We can find pointless evil-a.k.a. pointless suffering-in our backyard, so to speak. We don't need to bring God into it, and doing so may distract us into pursuing irrelevant issues.

The world may be better for some cases of suffering-people learn from their mistakes, criminals are locked up to protect the public, heroes risk their lives to save others-but it is worse for others-cases of extreme suffering that are un- 
deserved and of no benefit to anyone. Perhaps humans can't have one without the other, but if so, that mixture of good and evil is, in the judgment of atheists, more telling for naturalism than for theism.

The main issue, as I see it, is to identify the typical causes of pointless suffering, whether it is physical pain or emotional distress, and to explain how human beings, individually or collectively, can best intervene to prevent or reduce future cases of such suffering. In practical terms, that means everything we can do to educate people from being misled by mindless ideologies into treating other people as subhuman, everything we can do to aid the victims of natural disasters, and everything we can do to protect children and other powerless groups of people from being victimized by rapacious individuals, aided by public indifference. Needless to say, these are large tasks and it is doubtful whether theology will be useful or necessary to make progress with them. God, it is said, helps those who help themselves, so we cannot go wrong in undertaking to help ourselves.

\section{Conflicts of Interest}

The author declares no conflicts of interest regarding the publication of this paper.

\section{References}

Andre, S. (1985). The Problem of Evil and the Paradox of Friendly Atheism. International Journal for Philosophy of Religion, 17, 209-216. https://doi.org/10.1007/BF00134547

Andre, S. (1993). Was Hume an Atheist? Hume Studies, 19, 141-166. https://doi.org/10.1353/hms.2011.0401

Frankfurt, H. (1969). Alternate Possibilities and Moral Responsibility. The Journal of Philosophy, 66, 829-839. https://doi.org/10.2307/2023833

Frost, R. (1949). A Masque of Reason. In Complete Poems of Robert Frost 1949. New York: Henry Holt \& Company.

Hammond, A. (1956). Adapted from His Example, History of Philosophy Class. Baltimore, MD: McCoy College, Johns Hopkins University.

Hick, J. (1994). Evil and Soul-Making. In L. P. Pojman (Ed.), Philosophy of Religion: An Anthology (2nd ed., pp. 177-181). Belmont, CA: Wadsworth Publishing Co.

Hume, D. (1779). Dialogues Concerning Natural Religion. Book X. https://doi.org/10.1093/oseo/instance.00044084

Locke, J. (1689). Essay Concerning Human Understanding. Book Two, xxi, 10. https://doi.org/10.1093/oseo/instance.00018020

Mackie, J. L. (1955). Evil and Omnipotence. Mind, LXIV, 200-212. https://doi.org/10.1093/mind/LXIV.254.200

Paley, W. (1802). Natural Theology: Or, Evidences of the Existence and Attributes of the Deity Collected from the Appearances of Nature. London: R. Faulder.

Plantinga, A. (1974). God, Freedom, and Evil. Grand Rapids, MI: William B. Eerdmans Publishing Co.

Plantinga, A. (1983). Reason and Belief in God. In A. Plantinga, \& N. Wolterstorff (Eds.), Faith and Rationality (pp. 16-93). Notre Dame, IN: Notre Dame Press. Note the novel 
identification of God as a "person" rather than the conventional designation of him as a "being."

Plantinga, A. (1996). Epistemic Probability and Evil. In D. Howard-Snyder (Ed.), The Evidential Argument from Evil (pp. 69-96). Bloomington, IN: Indiana University Press.

Rowe, W. L. (1978). Philosophy of Religion: An Introduction. Belmont, CA: Wadsworth Publishing Co.

Rowe, W. L. (1979). The Problem of Evil and Some Varieties of Atheism. American Philosophical Quarterly, 16, 335-341.

Russell, B. (1996). Why Doesn't God Intervene to Prevent Evil? TheSecularWeb (Originally published in Pojman, L. P. (Ed.), Philosophy: The Quest for Truth (3rd ed., pp. 74-80). Belmont: Wadsworth.)

Sparrow, C. M. (1947). St. Augustine on Free Will (Trans.). Richmond, VA: University of Virginia Studies, The Dietz Press.

Swinburne, R. (2004). The Existence of God (2nd ed.). Oxford: Clarendon Press. https://doi.org/10.1093/acprof:oso/9780199271672.001.0001

van Inwagen, P. (2006). The Problem of Evil. The Gifford Lectures Delivered in the University of St Andrews in 2003, Oxford: Clarendon Press.

Wykstra, S. J. (1996). Rowe's Noseeum Arguments from Evil. In D. Howard-Snyder (Ed.), The Evidential Argument from Evil (pp. 126-150). Bloomington, IN: Indiana University Press. 